\title{
Could Alkali Production Be Considered an Approach for Caries Control?
}

\author{
V.V. Gordan ${ }^{\text {a }}$ C.W. Garvan ${ }^{d}$ M.E. Ottenga ${ }^{a}$ R. Schulte ${ }^{c}$ P.A. Harris ${ }^{a}$ \\ D. McEdward ${ }^{\text {a }}$ I. Magnusson ${ }^{b}$ \\ Departments of a Operative Dentistry and ${ }^{\mathrm{b}}$ Oral Biology, ${ }^{\mathrm{C} C o l l e g e ~ o f ~ D e n t i s t r y, ~ U n i v e r s i t y ~ o f ~ F l o r i d a, ~ a n d ~}$ \\ ${ }^{\mathrm{d} C o l l e g e}$ of Education, University of Florida, Gainesville, Fla., USA
}

\section{Key Words}

Alkali $\cdot$ Arginine $\cdot$ Bacteria $\cdot$ Plaque $\cdot$ Saliva $\cdot$ Urease

\begin{abstract}
This study investigated the relationship of arginine deiminase (ADS) and urease activities with dental caries through a case-control study. ADS and urease activities were measured in dental smooth-surface supragingival plaque and whole saliva samples from 93 subjects, who were in three different groups: caries-free $(n=31)$, caries-active $(n=30)$, and cariesexperienced $(n=32)$. ADS activity was measured by quantification of the ammonia generated from the incubation of plaque and saliva samples in a mixture containing $50 \mathrm{~mm}$ arginine- $\mathrm{HCl}$ and $50 \mathrm{~mm}$ Tris-maleate buffer, $\mathrm{pH}$ 6.0. ADSspecific activity was defined as nanomoles of ammonia generated per minute per milligram of protein. Urease activity was determined by quantification of ammonia produced from $50 \mathrm{~mm}$ urea. For bacterial identification and enumeration real-time qPCR analysis was used. Groups were compared using Kruskal-Wallis tests. Spearman correlations were used to analyze plaque metabolic activity and bacterial relationships. The results revealed significantly higher ammonia production from arginine in saliva (1.06 vs. $0.18 ; p<0.0001)$ and plaque samples ( 1.74 vs. $0.58 ; p<0.0001)$ from cariesfree subjects compared to caries-active subjects. Urease lev-
\end{abstract}

els were about 3-fold higher in the plaque of caries-free subjects $(p<0.0001)$. Although higher urease activity in saliva of caries-experienced and caries-free subjects was evident, no significant difference was found between the groups.

Copyright $\odot 2010$ S. Karger AG, Basel

Despite the advent of preventive dentistry several decades ago, dental caries still constitutes an important health problem and it is the most prevalent chronic disease in humans. Over $96 \%$ of adults and $99.5 \%$ of individuals 65 years of age or older in the United States have experienced dental caries [US Department of Health and Human Services, 2000]. The identification of individuals at higher risk for dental caries may significantly reduce the gravity and extent of this disease. Dental caries results from prolonged plaque acidification resulting from the metabolic activity of cariogenic microbiota, which leads to demineralization of the tooth. After sugar intake, the $\mathrm{pH}$ of dental plaque in situ falls rapidly, reaches a minimum value, and then gradually returns to its initial level [Stephan, 1940]. Some microbiological risk factors for dental caries have been identified [Van Wuyckhuyse et al., 1995; Burne and Marquis, 2000; Kleinberg, 2002] and with them the concept that an individual's change from caries-free to caries-active status may be related to a re-

\section{KARGER}

(C) 2010 S. Karger AG, Basel

Fax +41613061234 E-Mail karger@karger.ch www.karger.com www.karger.com/cre
Valeria V. Gordan

College of Dentistry, University of Florida

PO Box 100415, Gainesville, FL 32610-04415 (USA)

Tel. +1 352273 5846, Fax +1 3522737970

E-Mailvgordan@dental.ufl.edu 
Table 1. Epidemiologic profile of the study group

\begin{tabular}{|c|c|c|c|c|c|c|c|c|c|c|c|}
\hline \multirow[t]{2}{*}{ Age group } & \multicolumn{3}{|c|}{ Caries-free } & \multicolumn{4}{|c|}{ Caries-active } & \multicolumn{4}{|c|}{ Caries-experienced } \\
\hline & $\mathrm{n}$ & $\%$ of CF & DMFT & $\mathrm{n}$ & $\%$ of CA & MFT & DT & $\mathrm{n}$ & $\%$ of CE & MFT & DT \\
\hline $18-25$ & 10 & 42 & 0 & 6 & 15 & 5 & 9 & 10 & 27 & 6 & 0 \\
\hline $26-40$ & 16 & 50 & 0 & 10 & 31 & 9 & 6 & 10 & 33 & 5 & 0 \\
\hline 41 and older & 5 & 8 & 0 & 14 & 54 & 12 & 6 & 12 & 40 & 4 & 0 \\
\hline Total & 31 & 100 & & 30 & 100 & & & 32 & 100 & & \\
\hline
\end{tabular}

duced potential to generate alkali in the plaque, in addition to an increased acidogenic environment. The development of dental caries is usually a prolonged process involving cycles of demineralization and remineralization. When the demineralization phase dominates, a carious lesion is developed. Although plenty of studies have focused on the acidogenic nature of dental caries, ways to enhance the alkalinization phase and $\mathrm{pH}$ homeostasis have not been fully explored. Two significant sources of alkali in plaque are arginine and urea. Urea is hydrolyzed by urease enzymes which are present in a number of oral bacteria. Ammonia, generated from ureolysis, can lead to considerable increase in plaque $\mathrm{pH}$ despite a diet rich in carbohydrates [Kleinberg, 1961; Stephen, 1993; Imfeld et al., 1995; Clancy and Burne, 1997]. Ammonia can also be produced from arginine through the arginine deiminase system (ADS), which has not been thoroughly studied as a source for alkali production. However, enough in vitro evidence exists to support the hypothesis that ammonia production from urea and from arginine could be a major endogenous caries-inhibiting factor [Burne and Marquis, 2000]. Therefore, ammonia production through ureolysis and the ADS system could potentially inhibit the development of dental caries by neutralization of acids and stabilization of an oral microbiota that is congruent to dental health.

Besides affecting enamel stability, repeated acidification of plaque $\mathrm{pH}$ promotes the establishment of an acidogenic microbiota in dental plaque. This microbiota has been associated with an increased vulnerability to dental caries [Dennis et al., 1975; Loesche, 1986; Bradshaw et al., 1989; Marsh, 1994; Marsh and Bradshaw, 1995; Featherstone, 2000]. ADS and urease activity levels have not been defined clinically for adults. It is also unknown if ADS and urease levels are stable over time and/ or whether they vary significantly between caries-free and caries-active individuals.
Results from in vitro studies [Shu et al., 2003] and animal models [Clancy et al., 2000] support the concept that alkali-generating organisms may offer novel treatment and prevention strategies for caries disease. Existing literature also provides indirect support for the hypothesis that caries risk is directly associated with a loss of alkaligenerating potential [Kleinberg, 1961; Imfeld et al., 1995; Van Wuyckhuyse et al., 1995]. Arginine has already been incorporated into oral health products (arginine bicarbonate, Cavistat ${ }^{\circledR}$ ) [Chatterjee and Kleinberg, 2005], highlighting the importance of understanding the microbiology, biochemistry, and impact on oral health and disease of alkali-generating pathways. Therefore, the aims of the current study are (1) to assess the relationship of ADS and urease activity levels in plaque and saliva of adults with different caries status, and (2) to evaluate the association between ADS and urease activity levels with Streptococcus mutans and alkali-producing bacteria in dental plaque and saliva.

\section{Subjects and Methods}

\section{Study Design and Subject Population}

The study design was a case-control study. Ninety-three subjects were recruited from the dental clinics at the University of Florida, College of Dentistry. Subjects who met the inclusion/exclusion criteria and agreed to participate in the study signed a consent form approved by the University's Institutional Review Board. An epidemiological profile of the study population is presented in table 1.

Inclusion Criteria. Subjects who (1) were 18 years of age or older, (2) had at least 20 teeth, (3) had no contraindications to regular dental treatment and fell into one of the following groups: (a) were caries-free (total number of decayed, missing and filled teeth for each participant, DMFT $=0)$, (b) had at least 4 teeth with active caries (caries-active, number of decayed teeth, DT, for each participant $\geq 4$ ), or (c) had experienced caries in at least 4 teeth and had remained caries-free for at least 12 months (caries-experienced, number of missing and filled teeth, MFT, for each partici- 
pant $>4$ and number of decayed teeth, DT $=0$ ). Dental caries was scored visually based on the visual criteria of Ekstrand et al. [1997]. The DT and MFT values, respectively, for caries-active and caries-experienced groups were calculated separately. Once the study was completed, patients in the caries-active group were recommended standard care treatment as determined in the treatment planning clinic at the College of Dentistry.

Exclusion Criteria. Subjects who fit any one or more of the following criteria: (1) were younger than 18 years of age, (2) had less than 20 teeth, (3) had abnormally low flow rate of whole stimulated saliva (less than $0.5 \mathrm{ml} / \mathrm{min}$ and less than $0.7 \mathrm{ml} / \mathrm{min}$, for women and men, respectively) [Nauntofte et al., 2003], (4) had been treated within the 3 months that preceded the study with either antibiotics, systemic or inhaled steroids or with chlorhexidine, (5) were HIV-positive, (6) had removable or fixed dental appliances (braces, night-guard, removable partial dentures; they can lead to enhanced carbohydrate retention, more lactobacilli, and in turn to caries elevation) [Chatterjee and Kleinberg, 1979; Sakamaki and Bahn, 1968], (7) regularly used methamphetamine drugs, (8) regularly consumed more than 3 cans of cola per day, (9) had the habit of sucking on lemon with sugar, (10) had esophageal reflux disease, (11) had bulimia, (12) had a bleeding disorder or were on anticoagulant therapy, (13) had eaten in the past $12 \mathrm{~h}$ prior to sample collection, (14) had any oral hygiene procedures in the past $12 \mathrm{~h}$ prior to sample collection, or (15) were unwilling or unable to provide informed consent and follow instructions.

\section{Sample Collection and Preparation}

Smooth surface plaque (pooled) and whole unstimulated saliva samples were collected from all 93 subjects who were cariesfree $(\mathrm{n}=31)$, caries-active $(\mathrm{n}=30)$, and caries-experienced $(\mathrm{n}=$ 32). Subjects were required to refrain from practicing oral hygiene and eating (including chewing gum or candy, or drinking fluids other than water) for $12 \mathrm{~h}$ prior to sample collection. Supragingival plaque was collected from all smooth dental surfaces of incisors and molars [Denepitiya and Kleinberg, 1982] using sterile periodontal curettes (GR 3/46, curettes, Hu-Friedy Co., Chicago, Ill., USA). Sampling included interproximal, labial/buccal, and lingual surfaces of the teeth. Each portion of plaque scraped from surfaces of the teeth was immediately transferred to, and dispersed in, preweighed and sterile microcentrifuge tubes containing $10 \mathrm{mM} \mathrm{KPO}_{4}(\mathrm{pH} 7.0)$ buffer.

Whole unstimulated saliva was collected by asking the patients to expectorate into a sterile plastic container. A minimum of $5 \mathrm{ml}$ of saliva was collected.

Dental plaque and saliva samples were dispersed by external sonification (Heat Systems, Ultrasonics, Farmingdale, N.Y., USA) for two cycles of $15 \mathrm{~s}$, with cooling on ice during the interval. Plaque samples were washed once in sterile $10 \mathrm{~mm}$ Tris maleate ( $\mathrm{pH}$ 7.0) cold buffer, and resuspended in $500 \mu$ l of the same buffer in order to remove any background arginine and urea. ADS and urease activities in the samples were immediately measured using the standard biochemical assay described below. Aliquots of the samples were then stored frozen for identification and quantification of bacterial species through real-time quantitative polymerase chain reaction (qPCR).

Biochemical Measurement of ADS and Urease

ADS activity was measured by quantification of the ammonia generated from the incubation of resuspended dental plaque
$(25 \mu \mathrm{l})$ and saliva samples $(5 \mu \mathrm{l})$ in a mixture containing $50 \mathrm{mM}$ arginine-HCl (Sigma-Aldrich Canada, Oakville, Ont., Canada) and $0.5 \mathrm{~mm}$ Tris maleate buffer ( $\mathrm{pH} \mathrm{6.0)}$ for $90 \mathrm{~min}$ at $37^{\circ} \mathrm{C}$. After the incubation period, the ammonia produced was measured with the Nessler's reagent (Sigma-Aldrich, St. Louis, Mo., USA) using ammonium sulfate as the standard. Ammonia can be readily detected, in very minute traces, by the addition of Nessler's solution, which gives a distinct yellow coloration in the presence of the least trace of ammonia. The sensitivity of this method as a spot test is about $0.3 \mu \mathrm{g} \mathrm{NH}_{3}$ in $2 \mu \mathrm{l}$. The solution is then submitted to a Nessler cylinder, which is a simple type of colorimeter. Each sample was assayed in triplicate, and controls for background and interference were always included. Similarly, urease activity was measured by quantification of ammonia produced from $50 \mathrm{~mm}$ urea (Fisher Scientific, Pittsburgh, Pa., USA). ADS and urease activities were normalized to protein content and defined as micromoles ammonia liberated [ $\mathrm{min} \times(\mathrm{mg}$ of protein) $]^{-1}$.

In order to measure the amount of protein present in the samples, $200 \mu \mathrm{l}$ of the samples were mixed with $200 \mu \mathrm{l}$ of glass beads (0.1 mm, BioSpec Producers, Inc., Bartlesville, Okla., USA) following homogenization in a Bead Beater using two cycles of $30 \mathrm{~s}$, with cooling on ice during the interval. The samples were then centrifuged for $5 \mathrm{~min}$ at $13,000 \mathrm{~g}$ in a refrigerated microcentrifuge (Labnet International, Woodbridge, N.J., USA). Protein concentration of the supernatant fluid was determined using Bradford's [1976] method with the BioRad protein assay reagent (BioRad Laboratories, Hercules, Calif., USA) using bovine serum albumin as the standard.

\section{Bacterial Identification}

For bacterial identification and enumeration real-time qPCR analysis, the samples were dispersed as previously described under 'Sample Collection and Preparation' and separated by centrifugation for $2 \mathrm{~min}$ at $13,000 \mathrm{~g}$ in a refrigerated microcentrifuge (Lab net International, Woodbridge, N.J., USA). The supernatant fluids were disposed and the cells were resuspended in $480 \mu \mathrm{l}$ of $50 \mathrm{~mm}$ ethylenediaminetetraacetic acid. DNA was isolated using the Wizard ${ }^{\circledR}$ Genomic DNA Purification kit (Promega, Madison, Wisc., USA) according to the manufacturer's instructions. A total of 10 ng genomic DNA from each clinical sample was used in every real-time qPCR run.

In order to quantify alkali-producing bacteria, oligonucleotide primers (table 2) were designed using DNA MFOLD (http:// www.bioinfo.rpi.edu/) and BEACON DESIGNER 2.0 (premier Biosoft International, Palo Alto, Calif., USA). Species-specific primers were designed from the gtfB gene of $S$. mutans, the arginine deiminase genes of $S$. gordonii (arcA) and S. sanguinis (sagP), and urease subunit genes from A. naeslundii (ureA) and S. salivarius (ureC) were used. The $16 \mathrm{~S}$ ribosomal RNAs, universal oligonucleotide primers were also used. Gene levels were used in this study as a surrogate for bacterial numbers. Specificity of the primers was assessed using genomic DNA from a battery of oral bacterial reference strains and DNA isolated from pooled, human, whole saliva, which were used as templates for PCR. Standard curves for each gene were prepared [Yin et al., 2001] and used in every real-time qPCR run. A range of $10^{1}-10^{8}$ copies was found to be adequate for all the genes examined. Real-time qPCR was carried out in an iCycler $\mathrm{QQ}$ real-time qPCR detection system (BioRad Laboratories, Inc., Hercules, Calif., USA) using iQSYBR 
Table 2. Real-time PCR primers

\begin{tabular}{|c|c|c|c|}
\hline Bacterial strain & Target & Sequence & Product size, bp \\
\hline Universal for bacteria & 16S rRNA & $\begin{array}{l}\text { F-ACT ACG TGC CAG CAG CC } \\
\text { R-GGA CTA CCA GGG TAT CTA ATC C }\end{array}$ & $296-300$ \\
\hline S. mutans & $g t f B$ & $\begin{array}{l}\text { F-AGC CAT GCG CAA TCA ACA GGT T } \\
\text { R-CGC AAC GCG AAC ATC TTG ATC AG }\end{array}$ & 415 \\
\hline S. gordonii & $\operatorname{arc} A$ & $\begin{array}{l}\text { F-GCT ATT CGT GAG TTG CTT CAA GG } \\
\text { R-TTT GCT GCT TCT GGA ATT TCT GG }\end{array}$ & 107 \\
\hline S. sanguinis & $\operatorname{sag} P$ & $\begin{array}{l}\text { F-GTG GTG GTG GCA ATA TCG TAG } \\
\text { R-CGA CCT CGA ACC AAT TCA CTT CC }\end{array}$ & 178 \\
\hline A. naeslundii & ureA & $\begin{array}{l}\text { F-ACG AAG ACG CAA GGA CAG AGG } \\
\text { R-GTA GGC CAT GAG ATC CGT GAC C }\end{array}$ & 118 \\
\hline S. salivarius & ureC & $\begin{array}{l}\text { F-AGG TTC AGG TGG TGG ACA TGC } \\
\text { R-TTG TGG TGT ATG GGT TGA TTG GG }\end{array}$ & 98 \\
\hline
\end{tabular}

green supermix (BioRad Laboratories). A detailed genetic or microbiological analysis of all plaque samples was beyond the scope of the current study. For that reason, approximately 10 plaque samples with the highest and 10 with the lowest levels of alkaligenerating potential were selected for species-level quantification from each caries group.

\section{Statistical Issues}

Sample Size Estimation. A preliminary study was conducted and the results have been published elsewhere [Nascimento et al., 2009]. A power analysis was determined based on the results of the preliminary study and a sample size of 30 in each group (caries-free, caries-experienced, and caries-active) was necessary in order to detect a moderate (i.e., 0.5-0.8) effect size.

Statistical Analyses. Initially descriptive statistics utilizing graphical displays (such as box-and-whisker plots) were used to identify outliers and/or implausible values, to summarize the data, and to check for distributional forms. There were two observations that had implausible values for plaque mutans and these observations were excluded. Scatter plots of bivariate data were examined for possible nonlinear relationships. A two-sided alpha of 0.05 was used as the level of significance. SAS version 9.2 (SAS Institute, Cary, N.C., USA) was used for all data management and statistical analyses. To determine whether ADS and urease activity levels are associated with the numbers of $S$. mutans and selected alkali-producing bacterial species in the dental plaque, the number of bacteria in each sample was determined and normalized to milligrams of protein content of plaque and saliva. The bacteria were then grouped into two categories: A - S. mutans and B - alkali-producing species. Three possible variables were constructed: (1) total number of $S$. mutans per milliliter of clinical sample $(\mathrm{A} / \mathrm{ml}),(2)$ total numbers of alkali-producing bacteria per milliliter of clinical sample $(\mathrm{B} / \mathrm{ml})$, and (3) the ratio of $\mathrm{A} / \mathrm{B}$. Groups were compared using Kruskal-Wallis tests. Spearman correlations were used to analyze plaque metabolic activity and bacterial relationships.

\section{Results}

\section{ADS and Urease Activities in Plaque and in Saliva Samples}

Specific ADS and urease activities in plaque and in saliva of subjects who were either caries-free, caries-active, or caries-experienced were assessed by measuring the release of ammonia from arginine and urea. A significant alkali-producing potential was seen in both plaque and saliva of individuals with various caries status (table 3). Caries-free subjects presented significantly higher levels of ADS activity than caries-active subjects in both saliva (1.06 vs. $0.18 ; \mathrm{p}<0.0001)$ and plaque samples (1.74 vs. $0.58 ; \mathrm{p}<0.0001)$. Caries-free subjects also had 3 -fold higher urease levels than caries-active subjects (4.04 vs. $1.25 ; \mathrm{p}<0.0001)$ in plaque samples. Although higher urease activity was observed in saliva of cariesexperienced versus caries-free subjects, no significant difference was found between the groups $(\mathrm{p}=0.8274)$.

\section{Enumeration of S. mutans and Alkali-Producing \\ Bacteria and ADS and Urease Activities}

The mean level of $S$. mutans observed in the cariesactive group was higher (almost a 4 -fold difference) when compared to the caries-free and caries-experienced groups, but this difference was not significant $(p>0.05$; table 4). However, results of pairwise comparisons between caries-active and caries-free groups showed significant differences on $S$. mutans levels $(\mathrm{p}=0.0433)$. Lower mean levels of Streptococcus sanguinis, Streptococcus gordonii, Actinomyces naeslundii, and Streptococcus saliva- 
Table 3. Distribution of ADS and urease activities in plaque and in saliva samples according to caries status

\begin{tabular}{lllll}
\hline & $\begin{array}{l}\text { Caries- } \\
\text { free } \\
(\mathrm{n}=31)\end{array}$ & $\begin{array}{l}\text { Caries- } \\
\text { active } \\
(\mathrm{n}=30)\end{array}$ & $\begin{array}{l}\text { Caries-ex- } \\
\text { perienced } \\
(\mathrm{n}=32)\end{array}$ & p value $^{2}$ \\
\hline Plaque ADS & & & & $<0.0001$ \\
$\quad$ Mean & $1.74^{\mathrm{b}}$ & $0.58^{\mathrm{a}}$ & $1.51^{\mathrm{b}}$ & \\
$\quad$ Median & 1.50 & 0.55 & 1.42 & \\
$\quad$ SD & 1.32 & 0.35 & 1.09 & $<0.0001$ \\
Plaque urease & & & & \\
$\quad$ Mean & $4.04^{\mathrm{b}}$ & $1.25^{\mathrm{a}}$ & $3.51^{\mathrm{b}}$ & \\
$\quad \begin{array}{l}\text { Median } \\
\text { SD }\end{array}$ & 3.30 & 0.90 & 3.41 & \\
Saliva ADS & 3.13 & 1.29 & 2.57 & \\
$\quad$ Mean & $1.06^{\mathrm{b}}$ & $0.18^{\mathrm{a}}$ & $0.90^{\mathrm{b}}$ & \\
$\quad \begin{array}{l}\text { Median } \\
\text { SD }\end{array}$ & 0.63 & 0.12 & 0.70 & \\
Saliva urease & 1.00 & 0.18 & 0.71 & \\
$\quad$ Mean & $0.32^{\mathrm{a}}$ & $0.21^{\mathrm{a}}$ & $0.53^{\mathrm{a}}$ & \\
$\quad \begin{array}{l}\text { Median } \\
\text { SD }\end{array}$ & 0.15 & 0.10 & 0.12 & \\
\hline
\end{tabular}

${ }^{1}$ ADS and urease activity levels: $\mu \mathrm{mol}$ of ammonia liberated $\min ^{-1}$ (mg protein).

${ }^{2}$ Multiple comparisons: groups with same letter are not significantly different.

rius were observed for the caries-active group compared to caries-free and caries-experienced groups, but differences were not significant.

Spearman's correlation was used to evaluate the association between ADS and urease activity levels with S. mutans and alkali-producing bacteria in dental plaque (table 5). A significantly positive association was found between numbers of $S$. sanguinis and levels of ADS activity $(\mathrm{p}=0.0487)$ and numbers of $S$. salivarius and levels of urease active $(\mathrm{p}=0.0374)$. A significantly negative association was observed between numbers of $S$. mutans and levels of $\operatorname{ADS}(\mathrm{p}=0.0145)$ and urease $(\mathrm{p}=0.0499)$ activities.

\section{Discussion}

Margolis et al. [1988] have shown that a more alkaline resting plaque exists in caries-resistant compared to caries-susceptible individuals. It has been concluded that small differences in urea concentration and in the amount of urease enzyme may significantly affect the initiation and progress of dental caries [Chen et al., 2000]. The re-
Table 4. Distribution of oral bacteria counts in plaque according to caries status

\begin{tabular}{|c|c|c|c|c|}
\hline & $\begin{array}{l}\text { Caries- } \\
\text { free }\end{array}$ & $\begin{array}{l}\text { Caries- } \\
\text { active }\end{array}$ & $\begin{array}{l}\text { Caries-ex- } \\
\text { perienced }\end{array}$ & $\mathrm{p}$ value \\
\hline S. sanguinis & & & & 0.4010 \\
\hline Mean $^{1}$ & 0.48 & 0.20 & 0.76 & \\
\hline Median & 0.49 & 0.16 & 0.46 & \\
\hline $\mathrm{SD}$ & 0.34 & 0.18 & 1.0 & \\
\hline $\mathrm{n}$ & 8 & 7 & 5 & \\
\hline S. gordonii & & & & 0.3276 \\
\hline Mean ${ }^{1}$ & 0.31 & 0.15 & 0.29 & \\
\hline Median & 0.08 & 0.04 & 0.13 & \\
\hline $\mathrm{SD}$ & 0.41 & 0.19 & 0.37 & \\
\hline $\mathrm{n}$ & 8 & 7 & 5 & \\
\hline A. naeslundii & & & & 0.5946 \\
\hline Mean $^{1}$ & 0.67 & 0.09 & 0.11 & \\
\hline Median & 0.21 & 0.01 & 0.004 & \\
\hline $\mathrm{SD}$ & 0.99 & 0.15 & 0.26 & \\
\hline $\mathrm{n}$ & 11 & 13 & 9 & \\
\hline S. salivarius & & & & 0.2648 \\
\hline Mean $^{1}$ & 0.33 & 0.03 & 0.09 & \\
\hline Median & 0.05 & 0.01 & 0.004 & \\
\hline $\mathrm{SD}$ & 0.65 & 0.05 & 0.23 & \\
\hline $\mathrm{n}$ & 11 & 13 & 9 & \\
\hline S. mutans & & & & 0.0680 \\
\hline Mean $^{1}$ & 0.12 & 0.45 & 0.17 & \\
\hline Median & 0.002 & 0.01 & 0.001 & \\
\hline $\mathrm{SD}$ & 0.34 & 0.89 & 0.56 & \\
\hline $\mathrm{n}$ & 13 & 17 & 11 & \\
\hline
\end{tabular}

Results of pairwise comparisons: caries-active and caries-free are significantly different on $S$. mutans $(\mathrm{p}=0.0433) . \mathrm{n}$ is the number of participants for whom bacteria data count was available. For example, there were 8 participants in the caries-free group who had $S$. sanguinis data available.

${ }^{1}$ Dental plaque bacteria counts as determined by real-time qPCR and normalized by total bacteria.

Table 5. Relationship between ADS and urease activities and oral bacteria counts

\begin{tabular}{lll}
\hline Bacteria & $\begin{array}{l}\text { Spearman's } \\
\text { correlation } \\
\text { coefficient }\end{array}$ & p value \\
\hline Arginine plaque & & \\
$\quad$ S. sanguinis & 0.45 & 0.0487 \\
S. gordonii & -0.23 & 0.3388 \\
S. mutans & -0.38 & 0.0145 \\
Urease plaque & & \\
$\quad$ A. naeslundii & 0.10 & 0.5654 \\
S. salivarius & 0.36 & 0.0374 \\
S. mutans & -0.31 & 0.0499 \\
\hline
\end{tabular}


sults of the current study show that a positive relationship exists between high levels of alkali production and caries resistance as significantly higher levels of urease and ADS activities were seen in individuals experiencing no caries activity, compared with individuals who had active caries. Existing data indirectly support the idea that alkali production has an effect in plaque $\mathrm{pH}$ homeostasis. Part of this finding is reportedly related to increased ammonium concentrations in the plaque of caries-resistant individuals [Margolis et al., 1988]. Similarly, other clinical studies showed higher salivary urea concentrations in chronic renal failure patients [Shannon et al., 1977; Epstein et al., 1980], who, remarkably, showed very low incidence levels of dental caries despite a predominantly carbohydrate diet [Peterson et al., 1985].

The reason for the low alkali-producing activity in caries-active individuals may be related to a lack of urea as a substrate, resulting in lower numbers of urease-producing organisms and thus lower urease activity. Urea is naturally found in the oral cavity in all salivary secretions at concentrations approximating those in serum (i.e., $1^{-10} \mathrm{~mm}$ ) in healthy individuals [Kopstein and Wong, 1977]. Urea is not usually found in high quantities in dental plaque as it is rapidly hydrolyzed by the relatively high levels of urease present in plaque and saliva samples [Sissons et al., 1985]. However, it has been shown that individuals who produce low levels of urease have a reduced capacity to compensate glycolytic acidification even when provided with a large amount of urea [Sissons et al., 1985]. Therefore, it may be that individuals who present with low urease activity levels may actually have a reduced presence of urease-producing bacteria. Validating this thinking, the current study showed a significantly positive association between number of $S$. salivarius and levels of urease activity. S. salivarius uses urea as a source of nitrogen for growth through a urease-dependent pathway [Chen et al., 2000]. Studies have confirmed the ability of $S$. salivarius biofilm cells to regulate urease expression in response to $\mathrm{pH}$ increase with a significant impact on oral biofilm, $\mathrm{pH}$ homeostasis, and microbial ecology [Li et al., 2000]. It has been suggested that plaque ureolysis can be almost entirely explained by the percentage of total detectable ureolytic bacteria in the plaque microbiota [Sissons and Cutress, 1988]. In line with this thinking, the results of a previous in vitro study showed that levels of urease activity produced by a recombinant $S$. mutans strain could be manipulated, resulting in small increases in urease activity, which significantly decreased environmental acidification [Clancy and Burne, 1997]. In the current study, the urease activity in plaque of caries-free individuals was higher than in saliva samples of the same individuals. This is in agreement with previous studies in which the average rate of ureolysis in dental plaque was higher than in saliva by 2.5 -fold [Sissons and Cutress, 1988]. In that study 'plaque ureolysis rates were almost entirely explained by the percentage of total detectable ureolytic bacteria in the plaque microbiota' [Sissons and Cutress, 1988]. Another important variable that impacts urease activity is the oral environment. The environmental $\mathrm{pH}$ affects the ability of $S$. salivarius to metabolize urease, as studies have shown that $\mathrm{pH}$ levels below 4 may inactivate S. salivarius' urease [Sissons et al., 1990; Sissons and Hancock, 1993].

Despite a significant association between low caries activity and high levels of urease activity, no significant association was seen between low caries activity and numbers of certain alkali-producing bacteria. This finding suggests that merely changing the proportion of the studied alkali-producing bacteria may not necessarily change the caries susceptibility. Nonetheless the current study indicates the need to further investigate the phenotypic capacities of individual strains of oral bacteria. Even though the current study used genetic probes consistent with bacteria that are known to be urease-positive, it is possible that other nonidentified urease-positive bacteria may have been responsible for the high urease activity expression. The bacteria species have been selected based on existing genetic and microbiological knowledge of base-producing species. Other research groups are currently undertaking the investigation of novel species capable of hydrolyzing arginine and urea in clinical samples. As new organisms are identified, future studies can then explore and develop new sets of specific primers for the measurement of other alkali-producing bacteria.

Regarding ADS activity, even though previous studies revealed a relationship between elevated salivary arginine levels and caries resistance [Van Wuyckhuyse et al., 1995], no clinical studies thus far have correlated the capacity of oral biofilms to produce alkali from arginine with caries activity. The results of the current study show significantly different ADS activity levels between individuals with different caries status. The results confirm previous preliminary study, in which ADS activity levels in whole unstimulated saliva were higher in individuals who were caries-free [Nascimento et al., 2009]. Even though that study only showed a trend between caries status and ADS activity levels in supragingival dental plaque, the results of the current study, which has a higher sample size, showed significantly higher ADS activity levels in plaque for individuals who were caries-free. Ad- 
ditionally, the current study showed a significantly positive association between the number of $S$. sanguinis and levels of ADS activity. It is important to consider that the metabolic activity, including ADS and urease, is sensitive and the assay results can vary even within the same bacterial species or they can be different among bacterial strains of the same species. Another important point is that bacteria are highly dependent on the environment as far as acid or alkali production.

Previous studies have shown marked differences in bacterial species colonizing the oral soft tissues, surfaces, saliva, and supragingival plaque in healthy individuals [Mager et al., 2003]. Besides the diversity in site-specific colonization of oral bacteria there is also a distinct predominant bacterial microbiota that colonizes the healthy oral cavity which has not been fully defined. Ongoing combined efforts have focused on determining all bacterial species that are associated with health and dental caries [Aas et al., 2005, 2008; Keijser et al., 2008]. Fully understanding the role of bacteria present in oral health and in oral disease and their characterization are of paramount importance, so methods can be developed for biological intervention.

The development of dental caries is known to be a sitespecific process and one limitation of the current study is the fact that samples were not collected from occlusal surfaces. Continuing to study this subject, it will be one of the goals of future studies to develop sensitive methodologies that could be reliably applied to analysis of the biochemical activities and microbial populations associated with specific sites in the oral cavity, in recognition of the site-specific nature of the caries disease. We will, therefore, continue to actively investigate ways to measure urease and ADS activities in smaller site-specific plaque samples. However, one significant point of the current study was that we were able to measure statistically significant differences in plaque pooled from multiple sites in a given individual and to show meaningful differences between caries-active and caries-free subjects. Now that those differences have been established, novel ways to approach analysis of individual sites can be rationally designed.

In spite of the strength of the information now available, surprising gaps remain, particularly with respect to our knowledge of the distribution of the various catabolic pathways among microorganisms. To date it is not fully known if other caries control approaches, such as immunization or use of antimicrobial agents, may disturb the normal metabolic or physiologic pathways of the normal microbiota potentially leading to negative impact in the oral environment. The advantage that exploiting the ammonia-producing bacteria has over other approaches is that it may positively affect the plaque ecology by suppressing the manifestation of a cariogenic microbiota. Future research should now focus on establishing a causal relationship between alkali production and caries status and on establishing how consistent the levels of ADS and urease activities are over time in individuals who are caries-free.

In summary, the study showed a relationship between caries status and alkali production in the oral cavity. The direction of the relationship is that individuals who had active caries showed a reduced alkali-generating capacity of the bacteria colonizing the oral cavity. A significantly positive association exists between certain species of alkali-producing bacteria and levels of ADS and urease activities. A significantly negative association exists between numbers of $S$. mutans and levels of ADS and urease activities. Although a trend was observed between bacterial composition and caries status, no significant difference could be observed.

\section{Acknowledgments}

This investigation was supported by NIH-NIDCR grant 1R21 DE018392-01. Opinions and assertions contained herein are those of the authors and are not to be construed as necessarily representing the views of the respective organizations or the $\mathrm{Na}$ tional Institutes of Health. The informed consent of all human subjects who participated in this investigation was obtained after the nature of the procedures had been explained fully.

Publication of this article was funded in part by the University of Florida Open-Access Publishing Fund.

We would like to thank Dr. Marcelle M. Nascimento for assisting with the results for the real-time qPCR and Dr. Robert A. Burne for his advice at the conception of the study.

References

Aas JA, Griffen AL, Dardis SR, Lee AM, Olsen I, Dewhirst FE, Leys EJ, Paster BJ: Bacteria of dental caries in primary and permanent teeth in children and young adults. J Clin Microbiol 2008;46:1407-1417.

- Aas JA, Paster BJ, Stokes LN, Olsen I, Dewhirst FE: Defining the normal bacterial flora of the oral cavity. J Clin Microbiol 2005;43: 5721-5732.

Bradford MM: A rapid and sensitive method for the quantitation of microgram quantities of protein using the principal of protein-dye binding. Anal Biochem 1976;72:248-254.

Bradshaw DJ, McKee AS, Marsh PD: Effects of carbohydrate pulses and $\mathrm{pH}$ on population shifts within oral microbial communities. J Dent Res 1989;68:1298-1302. 
Burne RA, Marquis RE: Alkali production by oral bacteria and protection against dental caries. FEMS Microbiol Lett 2000;193:1-6.

-Chatterjee R, Kleinberg I: Effect of orthodontic band placement on the chemical composition of human incisor tooth plaque. Arch Oral Biol 1979;24:97-100.

Chatterjee R, Kleinberg I: Bacterial acidification and CaviStat ${ }^{\circledR}$ alkalinization of occlusal fissure pH (abstract 3264). J Dent Res 2005.

-Chen YY, Weaver CA, Burne RA: Dual functions of Streptococcus salivarius urease. J Bacteriol 2000;182:4667-4669.

- Clancy KA, Burne RA: Construction and characterization of a recombinant ureolytic Streptococcus mutans and its use to demonstrate the relationship of urease activity to pH modulating capacity. FEMS Microbiol Lett 1997;151:205-211.

-Clancy KA, Pearson S, Bowen WH, Burne RA: Characterization of recombinant, ureolytic Streptococcus mutans demonstrates an inverse relationship between dental plaque ureolytic capacity and cariogenicity. Infect Immun 2000;68:2621-2629.

Denepitiya L, Kleinberg I: A comparison of the microbial compositions of pooled human dental plaque and salivary sediment. Arch Oral Biol 1982;27:739-745.

-Dennis DA, Gawronski TH, Sudo SZ, Harris RS, Folke LA: Variations in microbial and biochemical components of four-day plaque during a four-week controlled diet period. J Dent Res 1975;54:716-722.

-Ekstrand KR, Ricketts DNJ, Kidd EAM: Reproducibility and accuracy of three methods for assessment of demineralization depth on the occlusal surface: an in vitro examination. Caries Res 1997;31:224-231.

-Epstein SR, Mandel I, Scoop IW: Salivary composition and calculus formation in patients undergoing hemodialyis. J Periodontol 1980; 51:336-338

- Featherstone JD: The science and practice of caries prevention. J Am Dent Assoc 2000;131: 887-899.

Imfeld TN, Birkhed D, Lingstrom P: Effect of urea in sugar-free chewing gums on $\mathrm{pH}$ recovery in human dental plaque evaluated with three different methods. Caries Res $1995 ; 29: 172-180$
Keijser BJF, Zaura E, Huse SM, van der Vossen JM, Schuren FH, Montijn RC, ten Cate JM, Crielaard W: Pyrosequencing analysis of the oral microflora of healthy adults. J Dent Res 2008;87:1016-1020

Kleinberg I: Effect of urea concentrations on plaque $\mathrm{pH}$ in vivo. J Dent Res 1961;40:751752.

Kleinberg I: A mixed-bacteria ecological approach to understanding the role of the oral bacteria in dental caries causation: an alternative to Streptococcus mutans and the specific-plaque hypothesis. Crit Rev Oral Biol Med 2002;13:108-125.

Kopstein J, Wong OM: The origin and fate of salivary urea and ammonia in man. Clin Sci Mol Med 1977;52:9-17.

Li YH, Chen YY, Burne RA: Regulation of urease gene expression by Streptococcus salivarius growing in biofilms. Environ Microbiol 2000;2:169-177.

Loesche WJ: Role of Streptococcus mutans in human dental decay. Microbiol Rev 1986;50 353-380.

-Mager Dl, Ximenez-Fyvie LA, Haffajee AD, Socransky SS: Distribution of selected bacterial species on intraoral surfaces. J Clin Periodontol 2003;30:644-654.

-Margolis HC, Duckworth JH, Moreno EC: Composition of pooled resting plaque fluid from caries-free and caries-susceptible individuals. J Dent Res 1988;67:1468-1475.

Marsh PD: Microbial ecology of dental plaque and its significance in health and disease. Adv Dent Res 1994;8:263-271.

Marsh PD, Bradshaw DJ: Dental plaque as a biofilm. J Ind Microbiol 1995;15:169-175.

-Nascimento MM, Gordan VV, Garvan CW, Browngardt CM, Burne RA: Correlations of oral bacterial arginine and urea catabolism with caries experience. Oral Microbiol Immunol 2009;24:89-95.

Nauntofte B, Tenovuo J, Lagerlöf F: Secretion and composition of saliva; in Fejerskov $\mathrm{O}$, Kidd EAM (eds): Dental Caries: the Disease and Its Clinical Management. Oxford, Blackwell Munksgaard, 2003, pp 7-27.

Peterson S, Woodhead J, Crall J: Caries resistance in children with chronic renal failure: plaque $\mathrm{pH}$, salivary $\mathrm{pH}$, and salivary composition. Pediatr Res 1985;19:796-799.

-Sakamaki ST, Bahn AN: Effect of orthodontic bonding on localized oral lactobacilli. J Dent Res 1968;47:275-279.
Shannon IL, Feller RP, Eknoyan G, Suddick RP: Human parotid saliva urea in renal failure and during dialysis. Arch Oral Biol 1977;22: 83-86.

-Shu M, Browgardt CM, Chen YY, Burne RA: Role of urease enzymes in stability of a 10 -species oral biofilm consortium cultivated in a constant-depth film fermenter. Infect Immun 2003;71:7188-7192. www.iai.asm. org/cgi/reprint/71/12/7188, 2003.

Sissons CH, Cutress TW, Pearce EI: Kinetics and product stoichiometry of ureolysis by human salivary bacteria and artificial mouth plaques. Arch Oral Biol 1985;30:781-790.

$\checkmark$ Sissons CH, Cutress TW: pH changes during simultaneous metabolism of urea and carbohydrate by human salivary bacteria in vitro. Arch Oral Biol 1988;33:579-587.

- Sissons CH, Hancock EM: Urease activity in Streptococcus salivarius at low $\mathrm{pH}$. Arch Oral Biol 1993;38:507-516.

Sissons CH, Perinpanayagam HE, Hancock EM, Cutress TW: $\mathrm{pH}$ regulation of urease levels in Streptococcus salivarius. J Dent Res 1990;69: 1131-1137.

Stephan RM: Changes in hydrogen-ion concentration on tooth surfaces and in carious lesions. J Am Dent Assoc 1940;27:718-723.

Stephen KW: Caries in young populations worldwide; in Bowen WH, Tabak LA (eds): Cariology for the Nineties. Rochester, University of Rochester Press, 1993, pp 37-50.

US Department of Health and Human Services. Oral Health in America: A Report of the Surgeon General. Rockville, US Department of Health and Human Service, National Institute of Dental and Craniofacial Research, National Institutes of Health, 2000.

-Van Wuyckhuyse BC, Perinpananayam HER, Bevacqua D, Raubertas RF, Billings RJ, Bowen WH, Tabak LA: Associations of free arginine and lysine concentrations in human parotid saliva with caries experience. J Dent Res 1995;74:686-690.

Yin JL, Shackel NA, Zekry A, McGuinness PH, Richards C, Putten KV, McCaughan GW, Eris JM, Bishop GA: Real-time reverse transcriptase-polymerase chain reaction (RTPCR) for measurement of cytokine and growth factor mRNA expression with fluorogenic probes or SYBR Green I. Immunol Cell Biol 2001;79:213-221. 